\title{
THE PROBLEMS OF PRESERVATION AND USE OF ARCHITECTURAL MONUMENTS OF THE FERGHANA REGION
}

\author{
Salimov Arif Muslimovich ${ }^{1}$ \\ DC's of Tashkent Architectural Building \\ Institute $^{1}$
}

\author{
Tursunova Dilnoza Raufjonovna ${ }^{2}$ \\ $\mathrm{PhD}$ applicant of Fergana Polytechnic Institute ${ }^{2}$
}

Article DOI: https://doi.org/10.36713/epra2277

\begin{abstract}
ANNOTATION
This article is about conservation and the use of monuments of folk architecture Ferghana Valley for modern function. Uzbekistan is a country of ancient culture that has given the world architecture excellent examples of architecture and art, and has exceptionally favorable conditions for the development of all forms of tourism.
\end{abstract}

KEY WORDS: Posho Prim, Margilan, monuments, history, builings, old buildings, multi-ethnic culture.

\section{INTRODUCTION}

Famous cities of around the world of Uzbekistan - Bukhara, Samarkand, Khiva and other cities, a large number of outstanding architectural monuments of the past, from the ancient Bactrian Kingdom to our time, have been preserved. Many of them are unique works of world architecture, preserved almost in its original form.[1]

\section{OBJECTIVES}

At present, every year the number of monuments of architecture, cultural heritage of peoples and archeology taken under state protection is revealed. In Uzbekistan, the number of them exceeds 10 thousand. They are scattered everywhere, especially in our ancient cities, but not everyone wants to notice them. One could read the history of Uzbekistan from these monuments alone in the main essays. The work of scientists to create a Set of historical and cultural monuments of the peoples of Uzbekistan helps to identify thousands of previously unknown, overlooked or not properly evaluated works of the past. Only in Uzbekistan, more than 4 thousand archaeological monuments, 3 thousand historical monuments, and more than 2 thousand monuments of architecture and monumental art are now registered.[1]

However, it is important not only to find and study monuments, but also to create conditions under which they will be preserved and used to the maximum extent in the life of modern society, in cultural and educational work, in the ideological, moral, aesthetic, cultural and spiritual education of the people. National policy provides, as you know, for the formation of a qualitatively new, unprecedented in history, multi- ethnic culture, which concentrates the achievements of the cultures of peoples of different nationalities. This requires us to pay great attention to the study, promotion and protection of cultural monuments of the Republic, Autonomous regions and national districts.[1,2]

\section{METHODOLOGY}

The solution of these complex problems is possible only at the level of modern science, with a broad generalization of the experience accumulated in this area. In recent years, there has been an extraordinary increase in interest in the study of historical and cultural heritage, and especially in its use. This is evidenced by a significant number of international scientific conferences and symposiums, a huge number of articles and other materials devoted to these problems. Of particular interest are the methodological aspects of the problem, because until recently we had serious shortcomings in the protection and use of monuments, which are overcome with great difficulty. When determining the nature of modern use of architectural monuments, there are no uniform rules that are suitable for all cases. A differentiated approach and consideration of the totality of specific facts and circumstances is needed to justify the optimal solution. The development of methods, research, and various factors that influence this decision are of great practical importance. This material, which is contained in the book, will be useful for everyone who is interested in the problems of protection and use of historical and cultural heritage and is working on problems. 


\section{STATISTICAL DESIGN}

Works of folk architecture in Uzbekistan, homes and quarter mosques, in their artistic value, deserve no less attention than monuments of monumental architecture. They are particularly in need of protection, because of the fragility and fragility of structures (broken clay, raw material, frame, beam covered), there are very few of them left. In accordance with current practice, protected mosques are rented out to various artels and production associations. But the problem is not so much in the fact of such a utilitarian use of buildings, as in the undifferentiated approach to them. A sad example of this is the Mirlyar mosque (1869) in the Suzuk-OTA mahalla in Tashkent, where mechanical workshops were located since the 30 s of the last century, which caused the magnificent paintings to die in the monument. As for old residential buildings, they were rebuilt, destroyed and destroyed over time. In the process of reconstruction, all the details of the wall ornament, painted plank ceilings, carved doors disappeared. Currently, in the "Suzik OTA" mahallas, a complete reconstruction is underway and all monuments-mosques that are in disrepair are being reconstructed.[2]

2018-19. at the suggestion of the Fergana regional society for the protection of historical and cultural monuments of Uzbekistan, more than 30 monuments of the city of Margilan and surrounding areas were examined - mainly mosques and Mazars (as the buildings over the grave of revered "saints" are called in Uzbekistan), as well as residential buildings. The buildings of the Ferghana valley, especially in Kokand, are distinguished by a high culture of decoration, primarily by the abundance and colorfulness of ceiling paintings.

With frequent alterations, houses constantly changed their appearance and few of them survived. Therefore, the identification of two old residential buildings can be considered a great success. In Kuva, part of the Zainiddin-boy house, built in 1899, has been preserved. Interesting construction plan and rich painting of the figured ceiling with raw walls, clayAdobe plaster and earthen floor in the area of Gulchaman in the Akhunbabayevsky district. The beams of its ceiling are painted on a red background with a simple floral pattern, blue, green and white paint, and the crates are painted in pairs of red and blue colors. The plan is symmetrical with openings along the axes of each wall. Above the door was a canopy (preserved in a later version). The building served, apparently, as a summer country house: you can still trace in the form of ramparts traces of the Adobe fence that surrounded the garden plot, and opposite the doorthe bed of the pond-house. The existence of such dacha buildings in the Ferghana valley in the past was known from survey data, but only one survived.

The decoration of mosques is of great artistic value. The combination of a sparse range of colors with the carving of the Hanako ceiling (1790) in Margilan conveys the features of the old local style. In a different manner, the ceiling of the Aivan of the Jami mosque in Kokand at the end of the XVIII century is made, where the main lines of the multicolored pattern are underlined with a lot. Many mosques in the Ferghana valley also had a rich and colorful wall decoration, but it has now been lost. The walls of the Kaftarlik mosque are bare, and it is hard to believe that they were once decorated with panels depicting flowers and landscapes.

The flat-roofed architecture of the Ferghana valley in its own way reflected the features of the monumental architecture of the major cultural centers of Uzbekistan. This affected the composition of the Cathedral (Friday) mosques. By the XVI century, a certain type of mosque was established-Namazgoh for citywide prayer on the annual holidays of Eid al-Fitr and Eid al-Fitr. Intended for a large gathering of people, Namazgohs were built outside the city and consisted of an expanded arcade on the Western side of a vast courtyard; the arcade was interrupted by a domed hall, spaced along the Central axis of the building. Friday mosques of the Ferghana valley repeat the composition of Namazgoh in the system of rack-and-beam construction: arcades with domes on pylons are replaced by rows of wooden columns bearing a beam earthen roof, a flat-roofed closed room is allocated for buildings. This type of mosque appeared to have developed by the 19th century and spread from Andijan to Kokand. The attached drawing shows schematic plans of five mosques of this type. They are dominated by an even number of naves, although the Mihrab located on the axis of the building is inevitably obscured by the middle row of columns. In contrast to the monumental Namazgoh, the facade of the closed hall of the Ferghana gallery mosques is always shaded by a portico. This part of Ayvan-has emphasized ceremonial forms: the slightly raised ceiling gets the form of figured plafonds with a rich overlay and colorful ornament, the Archi-i line is broken accordingly-the equivalent of the portal of monumental buildings, the so-called Kayvan, and the facade columns are crowned with magnificent capitals.[2]

Reproduction of techniques inherent in monumental architecture can be noticed in the area of decoration. The ceiling painting was dominated by relief ornament, where the main lines of the pattern were applied with a thick white mass-apparently, a special composition of purified ganch (local alabaster), then covered with gilding. This is a kind of equivalent of the relief ornament' kundal', which is famous for the Samarkand buildings of the time of the Temurids. That is a gilded pattern in high relief adorns the cornices of the ceiling of the mosque margilansai Haldiram and Kuva houses. The ornament of these buildings is unique.

Most of the monuments of Margilan are used for storage and production facilities. In the Friday mosques (the end of the XVIII century) and the Tumba of souls (the beginning of the XX century), warehouses of the city Trade were located. In the mosque of Shirma-Ghiyaz (XIX century) - the sewing shop of the 
mining Plant. In Dar mosque (1868) - the weaving shop of the society of the blind, and the walls, columns and ceiling of the Ivan are damaged by looms and mezzanines. A driving school is located in the Kazein mosque (the beginning of the XX century). Educational tables and billboards with ads are nailed on the walls with carved ornaments. The Department of preventive disinfection is located in the Khoja Igiz mosque (XIX century). Segamat Khoja mosque (beginning of XX century) with its beautiful painted ceilings is used as a dwelling house. The winter room of the Friday mosque (1903) in the village of Charvak in the Buvaydinsky district is used as a collective farm warehouse. Most of the buildings are empty.

Until now, not all architectural monuments have been taken under protection, for example, the Pirim mausoleum In Pakhtaabad. As a result, the monument was subjected to unauthorized repairs and its appearance was distorted - internal arches were laid, rough coating hid the brickwork of the facades and the edges of the domes. The same thing happened with the mausoleum of Buwayda (the same area), where the bookmark of the portal arch hid the inscription with the date of construction.[3]

\section{RESULTS}

Placement in monuments of any kind of production, where it is inevitable that any devices are attached to walls, columns, ceiling, mechanical damage, clogging, etc., should be categorically excluded. It is absolutely unacceptable to use mosques for housing.

It would be highly desirable to use mosques as premises for temporary or permanent exhibitions of local artistic crafts-ceramics, embroidery, wood carvings, etc. the Idea of using old mosques sometimes comes from the population. In the village of Shahristan (Shahand) in Namangan region, a local retired teacher suggested opening a Museum in one of the mosques in order to exhibit archaeological finds there. The organization of such a Museum in Shahriston district is not only appropriate, but highly desired: next to excavate in the mounds VIII., where the finds could go to the Museum, besides the modern village stands on the site of the city of X-XII centuries, the Excavations are visited by students, tourists of the neighboring resort, here comes the pioneers of the camps. The necessary repair of the premises was supposed to be carried out by public assistance as "hashar".[3]

Many works of folk art are lost, since neither the national nor regional museums collect details of collapsing buildings. Fragments of the ceiling, wall panels, parts of columns and carved doors must be preserved and exhibited. Concerted action should be taken between conservation societies and museums in this area.

\section{SUGGESTIONS}

It is known that scientific documentation of monuments is of great importance for the preservation of monuments. It is necessary to make detailed measurements of valuable objects, graphically fix plans, sections, and decorative elements. Every year, the flow of tourists and tourists to the historical cities of Uzbekistan increases. To acquaint them with the artistic culture of the republics, it is necessary to bring the cultural monuments in a satisfactory state of exposition. Each society has its own views on heritage and its own attitude to it.

The Republic of Uzbekistan has developed a method of approach to the artistic monuments of the past, which, on the one hand, is based on the principles of historical materialism, and on the other, is based on the need to organically combine the best of what humanity has created on the path of its development with the phenomena of modern culture. An active attitude to the heritage, the desire to " mobilize the past in the interests of the coming one, is characteristic of our entire practice of cultural construction and defines its important features. In other words, the process of forming historical culture does not negate or discard the achievements of past stages of development, but on the contrary, proceeds from the need to further deepen and improve everything valuable that is contained in the culture of the people. The more original and significant this culture is, the more masterpieces it enriches history, the more its monuments are included in the Treasury of the world's historical and artistic experience.[2]

At present, every year the number of monuments of architecture, cultural heritage of peoples and archeology taken under state protection is revealed. In Uzbekistan, the number of them exceeds 10 thousand. They are scattered everywhere, especially in our ancient cities, but not everyone wants to notice them. One could read the history of Uzbekistan from these monuments alone in the main essays. The work of scientists to create a Set of historical and cultural monuments of the peoples of Uzbekistan helps to identify thousands of previously unknown, overlooked or not properly evaluated works of the past. Only in Uzbekistan, more than 4 thousand archaeological monuments, 3 thousand historical monuments, and more than 2 thousand monuments of architecture and monumental art are now registered.

However, it is important not only to find and study the monuments, but also to create such conditions under which they will be provided for preservation and maximum use in the life of modern society, in cultural and educational work, in the ideological, moral, aesthetic, cultural and spiritual education of the people. National policy provides, as you know, for the formation of a qualitatively new, unprecedented in history, multi-ethnic culture, which concentrates the achievements of the cultures of peoples of different nationalities. This requires us to pay great attention to the study, promotion and protection of cultural monuments of the Republic, Autonomous regions and national districts.[3]

The solution of these complex problems is possible only at the level of modern science, with a broad generalization of the experience accumulated in 
this area. In recent years, there has been an extraordinary increase in interest in the study of historical and cultural heritage, and especially in its use. This is evidenced by a significant number of international scientific conferences and symposiums, a huge number of articles and other materials devoted to these problems. Of particular interest are the methodological aspects of the problem, because until recently we had serious shortcomings in the protection and use of monuments, which are overcome with great difficulty. When determining the nature of modern use of architectural monuments, there are no uniform rules that are suitable for all cases. A differentiated approach and consideration of the totality of specific facts and circumstances is needed to justify the optimal solution.

\section{CONCLUSION}

In conclusion the development of methods, research, and various factors that influence this decision are of great practical importance. This article will be useful for everyone who is interested in the protection and use of historical and cultural heritage and is working on problems.

\section{REFERENCES}

1. Azimov I.M. Architectural monuments of the Ferghana valley. "Uzbekistan". Tashkent in 1982.

2. Mirzaxmedov R., Murtazaev A., Margilan floor jewels. "Publishing house" Fergana". 2014.

3. Salimov A.M. Preservation and use of monuments architecture of Uzbekistan. "Science.", T., 2009, pg. 288. 